\title{
A comprehensive review of the benefits of Taraxacum officinale on human health
}

\author{
Agnese Di Napoli* (1) and Pietro Zucchetti
}

\begin{abstract}
Background: Taraxacum officinale (G.H. Weber ex Wiggers), commonly known as dandelion, is a herbaceous plant native to North America, Europe and Asia. This plant has been used for health purposes since ancient times. The phytochemicals present in different parts of the plant are responsible for its medicinal properties. In this review, we describe the main health properties of Taraxacum officinale.

Main body of the abstract: We searched for the main medicinal properties of Taraxacum officinale in the scientific literature, using the PubMed database. We selected 54 studies and we described twelve therapeutic properties, which are reported in previous studies. These properties are diuretic, hepatoprotective, anticolitis, immunoprotective, antiviral, antifungal, antibacterial, antiarthritic, antidiabetic, antiobesity, antioxidant and anticancer effects. We also found that the most frequently reported therapeutic effects include hepatoprotective, antioxidant and anticancer activities.
\end{abstract}

Short conclusion: In this review, we describe the medicinal properties of Taraxacum officinale reported in previous studies. Antioxidant, hepatoprotective and anticancer effects are mostly found in the scientific literature.

Keywords: Taraxacum officinale, Dandelion, Medicinal properties, Hepatoprotective, Antioxidant, Anticancer

\section{Background}

Taraxacum officinale (G.H. Weber ex Wiggers), commonly called dandelion, is a perennial plant belonging to the family Asteraceae. This plant is found in Europe, Asia and North America and is a very common weed spreading in gardens, agricultural crops, pastures and wasteland. The plant is about $40 \mathrm{~cm}$ tall and is characterized by yellow to orange flowers and jagged leaves (Fig. 1). The name "Taraxacum" comes from the Greek words "taraxos" (disorder) and "akos" (remedy). The word "officinale" denotes a plant having medicinal properties. It is noteworthy that this herb has been used as a medicinal plant from ancient times. The root and the young tops are mainly used for medicinal purposes (Grieve 1931; Rasool and Sharma 2014; Stewart-Wade et al. 2002). The young leaves of Taraxacum officinale are also used as a food in salads, drinks and vegetable dishes, due to its nutritional

\footnotetext{
*Correspondence: agnesedinapoli@outlook.com Istituto Italiano Di Permacultura, Loc. Gambaldo n.1 Via Torino, 12070 Scagnello, CN, Italy
}

value. Research studies show that the Taraxacum officinale leaves contain high concentrations of fiber, minerals, vitamins and essential fatty acids (Escudero et al. 2003).

Taraxacum officinale has many medicinal properties, due to phytochemicals found in flower, leaf and stem and roots of the plant. The main phytochemicals are: carotenoids; flavonoids (e.g., quercetin, chrysoeriol, luteolin-7-glucoside); phenolic acids (e.g., caffeic acid, chlorogenic acid, chicoric acid); polysaccharides (e.g., inulin); sesquiterpene lactones (e.g., taraxinic acid, taraxacoside, $11 \beta, 13$-dihydrolactucin, ixerin $\mathrm{D}$, taraxacolide-O- $\beta$ glucopyranoside); sterols (e.g., taraxasterol, $\beta$-sitosterol, stigmasterol); triterpenes (e.g., $\alpha$-amyrin) (Amin Mir et al. 2013; Singh et al. 2008) (Fig. 2).

There are more than 2500 different species of Taraxacum and the most studied are T. officinale, T. mongolicum, T. platycarpum, T. laevigatum and T. kok-saghyz. Taraxacum officinale represents the most studied specie and the main species are native to different parts of the world. For example, T. mongolicum, T. platycarpum, T. laevigatum and T. kok-saghyz are native to China, 


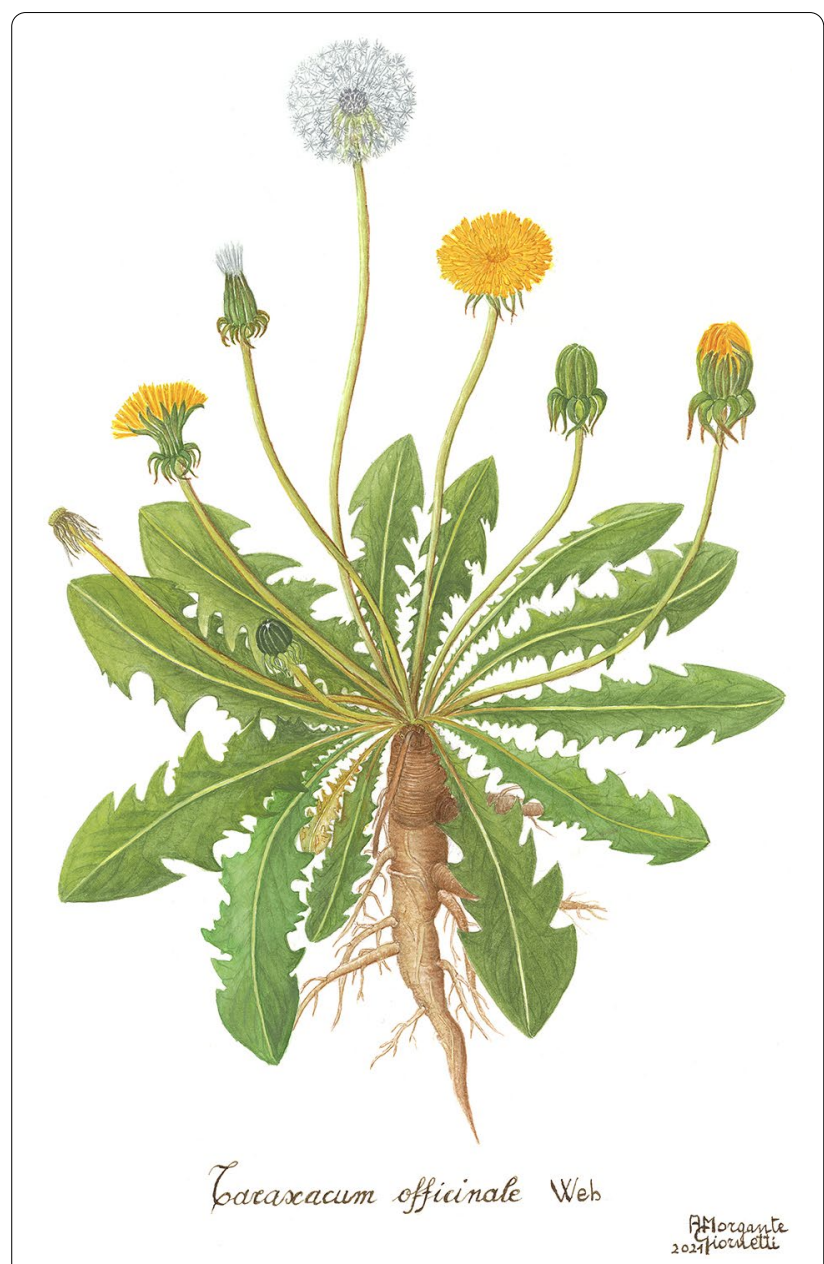

Fig. 1 Taraxacum officinale. A botanical illustration of the plant ("Taraxacum officinale Web" by Adriana Morgante Giornetti)

Korea, Europe and Central Asia, respectively. Taraxacum is used for similar medicinal purposes in different countries, although some species native to a particular region have uncommon medicinal uses. For example, $T$. crepidiforme is used for treating eyes disease in Turkey (Martinez et al. 2015).

The aim of this review is to find the main medicinal properties of Taraxacum officinale, searching the scientific literature. This plant has a very important role in traditional and complementary medicine and is used by physicians and herbalists to solve many health problems. For this reason, this review is of great importance for all the practitioners who can use this plant as a health remedy. This work is also relevant for the researchers who are studying the medicinal properties of Taraxacum officinale, as they will know the latest research findings in this field.

\section{Main text}

We searched for scientific articles related to the effects of Taraxacum officinale on human health using PubMed (www.ncbi.nlm.nih.gov/pubmed). We used the following keywords: "Taraxacum officinale", "dandelion", "properties of Taraxacum officinale", "properties of dandelion", "phytoterapy of Taraxacum officinale" and "Taraxacum officinale and disease treatment". Then we extended our search using the following keywords: "diuretic Taraxacum officinale", "hepatoprotective Taraxacum officinale", "Taraxacum officinale and colitis", "immune effects of Taraxacum officinale", "antiviral Taraxacum officinale", "antifungal Taraxacum officinale", "antibacterial Taraxacum officinale", "antiarthritic Taraxacum officinale", "antidiabetic Taraxacum officinale", "antiobesity Taraxacum officinale", "antioxidant activity Taraxacum officinale" and "anticancer Taraxacum officinale".

Firstly, scientific articles were selected depending on their titles. Secondly, we read the abstracts and we selected only the articles relevant to the topic of the present study. Finally, we read all the selected articles and we chose the articles suitable for our research.

In total, we found 54 studies relevant to the topic of this review. The results show that twelve medicinal properties of Taraxacum officinale are reported in the scientific literature. These properties include diuretic (4 studies), hepatoprotective (7 studies), anticolitis (5 studies), immunoprotective (4 studies), antiviral (5 studies), antifungal (1 study), antibacterial (4 studies), antiarthritic (1 study), antidiabetic (5 studies), antiobesity (6 studies), antioxidant (12 studies) and anticancer (7 studies) activities. The therapeutic effects of Taraxacum officinale which are mostly reported in the scientific literature are antioxidant, hepatoprotective and anticancer activities.

\section{Diuretic activity and treatment of urological diseases}

One previous study found that Taraxacum officinale extracts have diuretic activity in a mouse model (RâczKotilla et al. 1974). A study by Clare et al. (2009) showed that this plant ethanolic leaves extract increases urinary frequency and fluid excretion in healthy individuals. Other two studies showed a positive effect of Taraxacum officinale extract on the treatment and prevention of kidney diseases, such as urolithiasis (Ghale-Salimi et al. 2018; Karakus et al. 2017) (Table 1).

\section{Hepatoprotective effects}

Research studies reveal that Taraxacum officinale is useful for preventing and treating liver diseases. One study showed that two polysaccharides found in this plant are effective for preventing acetaminophen (APAP)-induced liver injury (AILI) in a mouse model (Cai et al. 2017). 


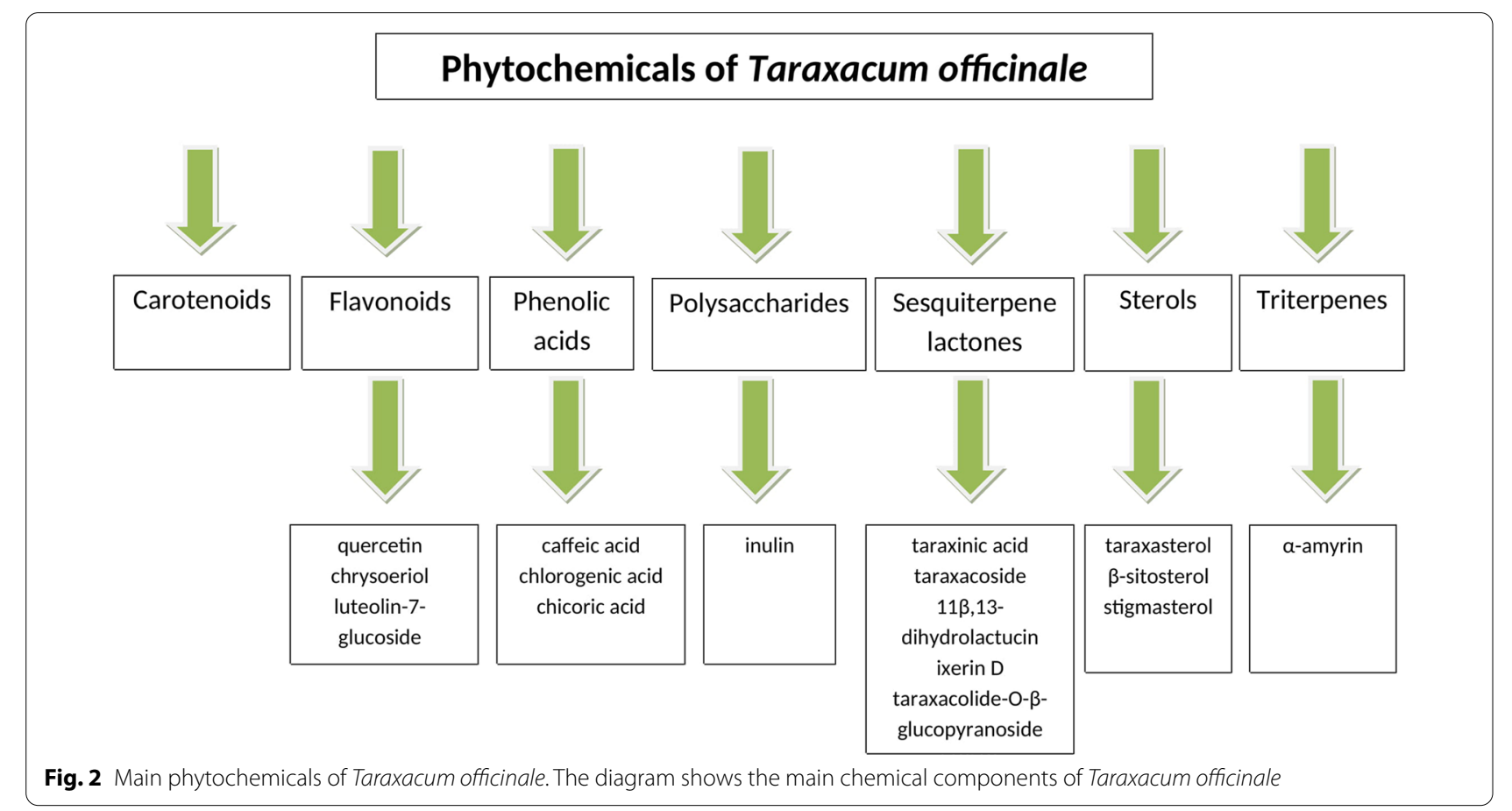

Table 1 Medicinal properties of Taraxacum officinale. The results of literature review are reported in the table

\begin{tabular}{|c|c|}
\hline Medicinal properties of Taraxacum officinale & References \\
\hline Diuretic activity and treatment of urological diseases & Clare et al. (2009), Ghale-Salimi et al. (2018), Karakus et al. (2017), Râcz-Kotilla et al. (1974) \\
\hline Hepatoprotective effects & $\begin{array}{l}\text { Cai et al. (2017), Colle et al. (2012); Davaatseren et al. (2013a), Davaatseren et al. (2013b), Hfaiedh } \\
\text { et al. (2016), Park et al. (2010), You et al. (2010) }\end{array}$ \\
\hline Treatment of colitis & Chen et al. (2019a), Chen et al. (2019b), Ding and Wen (2018), Han et al. (2017), Wang et al. (2017) \\
\hline Effects on the immune system & Kim et al. (1998), Lee et al. (2012), Sang et al.(2019), Tan et al.(2017) \\
\hline Antiviral effects & $\begin{array}{l}\text { Flores-Ocelotl et al. (2018), Han et al. (2011), He et al. (2011), Rehman et al. (2016), Yang et al. } \\
\text { (2020) }\end{array}$ \\
\hline Antifungal activity & Liang et al. (2020) \\
\hline Antibacterial activity & Diaz et al. (2018), Kenny et al. (2015), Qian et al. (2014), Wang (2014) \\
\hline Antiarthritic activity & Wang et al. (2016) \\
\hline Antidiabetic effects & $\begin{array}{l}\text { Akhtar et al. (1985), Choi et al. (2018), Davaatseren et al. (2013b), Guo et al. (2019), Hussain et al. } \\
\text { (2004) }\end{array}$ \\
\hline Antiobesity activity & $\begin{array}{l}\text { Aabideen et al. (2020), Choi et al. (2010), García-Carrasco et al. (2015), Davaatseren et al. (2013b), } \\
\text { Râcz-Kotilla et al. (1974), Zhang et al. (2008) }\end{array}$ \\
\hline Antioxidant activity & $\begin{array}{l}\text { Aabideen et al. (2020), Choi et al. (2010), García-Carrasco et al. (2015), Guo et al. (2019), Hu and } \\
\text { Kitts (2005), Ivanov et al. (2018), Jedrejek et al. (2017), Jedrejek et al. (2019), Lis et al. (2020), } \\
\text { Milek et al. (2019), Park et al. (2011), Park et al. (2014) }\end{array}$ \\
\hline Anticancer effects & $\begin{array}{l}\text { Nassan et al. (2018), Nguyen et al. (2019), Ovadje et al. (2011), Ovadje et al. (2012), Ovadje et al. } \\
\text { (2016), Saratale et al. (2018), Sigstedt et al. (2008) }\end{array}$ \\
\hline
\end{tabular}

A study by Colle et al. (2012) found that this plant leaf extract has hepatoprotective activity against APAP toxicity. Other studies demontrated that Taraxacum officinale leaves extract is able to prevent and treat non-alcoholic fatty liver disease (NAFLD) (Davaatseren et al. 2013a, 2013b). One previous study showed that this plant leaf extract has hepatoprotective activity against sodium dichromate-induced liver injury in vivo (Hfaiedh et al. 2016). A study by You et al. (2010) found that Taraxacum officinale root aqueous extract can prevent alcoholinduced liver damage and another study showed that two polysaccharides isolated from this plant exert protective 
effects against hepatic damage in vivo (Park et al. 2010) (Table 1).

\section{Activity against colitis}

A previous study showed that Taraxacum officinale root extract can exert therapeutic property in ulcerative colitis, using in vitro and in vivo models (Ding and Wen 2018). Another study found that this plant is able to prevent colitis in a mouse model. In this study, Taraxacum officinale extract seems to have a stronger effect than an anti-inflammatory drug on preventing colitis. In particular, this plant prevented colitis through anti-oxidative, anti-inflammatory and regenerative activities (Han et al. 2017). One previous study found that a Taraxacum officinale polysaccharide can ameliorate ulcerative colitis (Wang et al. 2017). Another study demonstrated that taraxasterol is effective in the treatment of acute colitis in vivo (Chen et al. 2019a). Finally, a study by Chen et al. (2019b) showed that Taraxacum officinale extract is able to improve the symptoms of colitis controlling fatty acid metabolism and dysbiosis (Table1).

\section{Effects on the immune system}

Previous studies found that Taraxacum officinale extract improves immunity, increasing nitric oxide (NO) and cytokines production in mice (Kim et al. 1998; Lee et al. 2012). Another study showed that taraxasterol can activate the $\mathrm{Bax} / \mathrm{Bc1}-2$ anti-apoptotic signalling pathway, which is downregulated in autoimmune disorders (Sang et al. 2019). A study by Tan et al. (2017) found that Taraxacum officinale extracts ameliorate the immune response in vivo (Table 1).

\section{Antiviral activity}

A study by Han et al. (2011) showed that aqueous Taraxacum officinale extract has antiviral activity in vitro, inhibiting human immunodeficiency virus type 1 (HIV1) reverse transcription and replication. Another study found that this plant extract is able to prevent influenza infections by inhibiting virus replication (He et al. 2011). A recent study by Yang et al. (2020) showed that Taraxacum officinale extract has antiviral activity in vitro against hepatitis B virus (HBV) and the bioactive compound which exerts this action is taraxasterol. Other studies found that this plant extract has antiviral activity against the dengue virus serotype 2 (DENV2) (Flores-Ocelotl et al. 2018) and the hepatitis C virus (HCV) (Rehman et al. 2016) (Table 1).

\section{Antifungal activity}

A recent study by Liang et al. (2020) found that Taraxacum officinale can inhibit Candida albicans by disrupting the cell wall (Table 1).

\section{Antiarthritic activity}

A previous study showed that taraxasterol from Taraxacum officinale possesses antiarthritic effect by inhibiting inflammation in vivo (Wang et al. 2016) (Table 1).

\section{Antibacterial activity}

Two previous studies found that oligosaccharides and polysaccharides isolated from Taraxacum officinale exhibit an antibacterial effect against Staphylococcus aureus, Escherichia coli and Bacillus subtilis (Qian et al. 2014; Wang 2014). A study by Kenny et al. (2015) showed that Taraxacum officinale root extract has antibacterial activity against Staphylococcus aureus and Bacillus cereus. Another study found that Taraxacum officinale leaves extract has strong antibacterial properties against Staphylococcus aureus and moderate antibacterial activity against Escherichia coli, Klebsiella pneumoniae and Proteus mirabilis (Diaz et al. 2018) (Table 1).

\section{Antidiabetic activity}

Two previous studies found that compounds isolated from Taraxacum officinale exhibit hypoglycemic effects via inhibition of $\alpha$-glucosidase and $\alpha$-amylase (Choi et al. 2018; Guo et al. 2019). Another study showed that this plant has hypoglycemic properties in an animal model and this effect might be exerted by improving insulin secretion from the $\beta$-cells of the pancreatic islets (Akhtar et al. 1985). Another study found that Taraxacum officinale leaf extract lowers fasting blood glucose level and insulin resistance in vivo (Davaatseren et al. 2013b). A study by Hussain et al. (2004) showed that Taraxacum officinale extract enhances insulin secretion from pancreatic $\beta$-cells in vitro (Table 1 ).

\section{Antiobesity activity}

One study found that Taraxacum officinale extracts are able to reduce body weight in a mouse model (RâczKotilla et al. 1974). Previous studies showed that Taraxacum officinale exerts hypolipidemic effects in vivo (Choi et al. 2010; Davaatseren et al. 2013b) and in vitro (GarcíaCarrasco et al. 2015). A study by Zhang et al. (2008) showed that Taraxacum officinale can inhibit pancreatic lipase in vivo and in vitro and can have an anti-obesity effect. A recent study by Aabideen et al. (2020) found that this plant has hypolipidemic activity via inhibition of pancreatic lipase (Table 1).

\section{Antioxidant activity}

Previous studies showed that Taraxacum officinale has antioxidant activity in vivo (Choi et al. 2010) and in vitro (Ivanov et al. 2018; Milek et al. 2019; Park et al. 2011). Two studies found that polysaccharides from this plant have antioxidant activity in vitro (Guo et al. 2019; Park 
et al. 2014). Other studies demonstrated that polyphenols contained in Taraxacum officinale exert antioxidant effects in vitro (Aabideen et al. 2020; García-Carrasco et al. 2015; Hu and Kitts, 2005; Jedrejek et al. 2017; Jedrejek et al. 2019; Lis et al. 2020) (Table 1).

\section{Anticancer activity}

Previous studies showed that Taraxacum officinale has anticancer activity in different types of cancer. One study showed that Taraxacum officinale extracts block proliferation and invasion of breast and prostate cancer cells (Sigstedt et al. 2008). Another study demonstrated that this plant extract can inhibit proliferation and growth of breast cancer cells, regulating phosphatidylinositol 3-kinase (PI3K)/ protein kinase B (AKT) pathway (Nassan et al. 2018). A study by Saratale et al. (2018) showed that Taraxacum officinale exerts cytotoxicity effects on human hepatic cancer cells. In vivo and in vitro studies found that this plant extracts can induce programmed cell death in different categories of cancer cells, such as human leukemia, colorectal, prostate and pancreatic cancer cells (Nguyen et al. 2019; Ovadje et al. 2011; Ovadje et al. 2012; Ovadje et al. 2016) (Table 1).

A limitation of this review is that only published studies are included. Moreover we used personal criteria for selecting articles and it could influence results and conclusions.

\section{Conclusion}

This review shows that twelve medicinal properties of Taraxacum officinale are commonly reported in the scientific literature. These properties comprise diuretic, hepatoprotective, anticolitis, immunoprotective, antiviral, antifungal, antibacterial, antiarthritic, antidiabetic, antiobesity, antioxidant and anticancer effects. Hepatoprotective, antioxidant and anticancer activities are the most frequently reported medicinal properties of Taraxacum officinale in the scientific literature. This plant represents a promising source for the prevention and treatment of health conditions. The protective action of Taraxacum officinale against hepatotoxicity, oxidative stress and cancer cell proliferation is well reported in the scientific literature. Further research is needed for validating the medicinal properties previously described and for corroborating the use of this plant as a health remedy.

\footnotetext{
Abbreviations

AILI: APAP-induced liver injury; AKT: Protein kinase B; APAP: Acetaminophen; BCSCs: Breast cancer stem cells; DENV2: Dengue virus serotype 2; HBV: Hepatitis B virus; HCV: Hepatitis C virus; HIV-1: Human immunodeficiency virus type 1; NAFLD: Non-alcoholic fatty liver disease; NO: Nitric oxide; PI3K: Phosphatidylinositol 3-kinase; ROS: Reactive oxygen species; TRAIL: Tumor necrosis factor-related apoptosis-inducing ligand.
}

Acknowledgements

We would like to thank Maurizio Carturan and Lidia Novelli for their valuable support on this project.

\section{Authors' contributions}

$A D N$ and $P Z$ designed the study. ADN performed the literature search and wrote the first draft of the manuscript. ADN and PZ contributed to the final version of the manuscript. The authors read and approved the final manuscript.

\section{Funding}

This research has not received any funding.

Availability of data and material

All data and material are available upon request.

\section{Declarations}

Ethics approval and consent to participate

Not applicable

\section{Consent for publication}

Not applicable

\section{Competing interests}

No competing interests to declare.

Received: 11 May 2021 Accepted: 3 June 2021

Published online: 09 June 2021

\section{References}

Aabideen ZU, Mumtaz MW, Akhtar MT, Mukhtar H, Raza SA, Touqeer T, Saari N (2020) Anti-obesity attributes; UHPLC-QTOF-MS/MS-based metabolite profiling and molecular docking insights of Taraxacum officinale. Molecules 25(4935):1-20

Akhtar MS, Khan QM, Khaliq T (1985) Effects of Portulaca oleracae (Kulfa) and Taraxacum officinale (Dhudhal) in normoglycaemic and alloxan-treated hyperglycaemic rabbits. J Pak Med Assoc 35(7):207-210

Amin Mir M, Sawhney SS, Jassal MMS (2013) Qualitative and quantitative analysis of phytochemicals of Taraxacum officinale. Wudpecker J Pharm and Pharmocol 2(1):001-005

Cai L, Wan D, Yi F, Luan L (2017) Purification, preliminary characterization and hepatoprotective effects of polysaccharides from dandelion root. Molecules 22(1409):1-15

Chen W, Da W, Li C, Fan H, Liang R, Yuan J, Huang X, Yang R, Zhang J, Zhu J (2019a) Network pharmacology-based identification of the protective mechanisms of taraxasterol in experimental colitis. Int Immunopharmacol 71:259-266

Chen W, Fan H, Liang R, Zhang R, Zhang J, Zhu J (2019b) Taraxacum officinale extract ameliorates dextran sodium sulphate-induced colitis by regulating fatty acid degradation and microbial dysbiosis. J Cell Mol Med 23:8161-8172

Choi J, Yoon KD, Kim J (2018) Chemical constituents from Taraxacum officinale and their a-glucosidase inhibitory activities. Bioorg Med Chem Lett 28(3):476-481

Choi UK, Lee OH, Yim JH, Cho CW, Rhee YK, Lim SI, Kim YC (2010) Hypolipidemic and antioxidant effects of dandelion (Taraxacum officinale) root and leaf on cholesterol-fed rabbits. Int J Mol Sci 11:67-78

Clare BA, Conroy RS, Spelman K (2009) The diuretic effect in human subjects of an extract of Taraxacum officinale folium over a single day. J Altern Compl Med 15(8):929-934

Colle D, Arantes LP, Gubert P, Almeida da Luz SC, Athayde ML, Teixeira Rocha JB, Antunes Soares FA (2012) Antioxidant properties of Taraxacum officinale leaf extract are involved in the protective effect against hepatoxicity induced by acetaminophen in mice. J Med Food. 15(6):42-48.

Davaatseren M, Hur HJ, Yang HJ, Hwang JT, Park JH, Kim HJ, Kim MS, Kim MJ, Kwon DY, Sung MJ (2013a) Dandelion leaf extract protects against liver 
injury induced by methionine- and choline- deficient diet in mice. J Med Food 16(1):26-33

Davaatseren M, Hur HJ, Yang HJ, Hwang JT, Park JH, Kim HJ, Kim MJ, Kwon DY, Sung MJ (2013b) Taraxacum official (dandelion) leaf extract alleviates high-fat diet-induced nonalcoholic fatty liver. Food Chem Toxicol 58:30-36

Diaz K, Espinoza L, Madrid A, Pizarro L, Chamy R (2018) Isolation and identification of compounds from bioactive extracts of Taraxacum officinale Weber ex F. H. Wigg. (dandelion) as a potential source of antibacterial agents. Evid Based Complement Alternat Med. 8:1-8.

Ding A, Wen X (2018) Dandelion root extract protects NCM460 colonic cells and relieves experimental mouse colitis. J Nat Med 72:857-866

Escudero NL, De Arellano ML, Fernàndez S, Albarracìn G, Mucciarelli S (2003) Taraxacum officinale as a food source. Plant Foods Hum Nutr 58:1-10

Flores-Ocelotl MR, Rosas-Murrieta NH, Moreno DA, Vallejo-Ruiz V, Reyes-Leyva J, Domínguez F, Santos-López G (2018) Taraxacum officinale and Urtica dioica extracts inhibit dengue virus serotype 2 replication in vitro. BMC Complement Altern Med 18(95):1-10

García-Carrasco B, Fernandez-Dacosta R, Dávalos A, Ordovás JM, RodriguezCasado A (2015) In vitro hypolipidemic and antioxidant effects of leaf and root extracts of Taraxacum officinale. Med Sci 3:38-54

Ghale-Salimi MY, Eidi M, Ghaemi N, Khavari-Nejad RA (2018) Inhibitory effects of taraxasterol and aqueous extract of Taraxacum officinale on calcium oxalate crystallization: in vitro study. Ren Fail 40(1):298-305

Grieve M (1931) A modern herbal. Dover Publications, New York

Guo H, Zhang W, Jiang Y, Wang H, Chen G, Guo M (2019) Physicochemical, structural, and biological properties of polysaccharides from dandelion. Molecules 24(1485):1-14

Han H, He W, Wang W, Gao B (2011) Inhibitory effect of aqueous dandelion extract on HIV-1 replication and reverse transcriptase activity. BMC Complement Altern Med 11(112):1-10

Han KH, Park JM, Jeong M, Han YM, Go EJ, Park J, Kim H, Han JG, Kwon O, Hahm KB (2017) Heme oxygenase-1 induction and anti-inflammatory actions of Atractylodes macrocephala and Taraxacum herba extracts prevented colitis and was more effective than sulfasalazine in preventing relapse. Gut Liver 11(5):655-666

He W, Han H, Wang W, Gao B (2011) Anti-influenza virus effect of aqueous extracts from dandelion. Virol J 8(538):1-11

Hfaiedh M, Brahmi D, Zourgui L (2016) Hepatoprotective effect of Taraxacum officinale leaf extract on sodium dichromate-induced liver injury in rats. Environ Toxicol 31(3):339-349

Hu C, Kitts DD (2005) Dandelion (Taraxacum officinale) flower extract suppresses both reactive oxygen species and nitric oxide and prevents lipid oxidation in vitro. Phytomedicine 12:588-597

Hussain Z, Waheed A, Qureshi RA, Burdi DK, Verspohl EJ, Khan N, Hasan M (2004) The effect of medicinal plants of Islamabad and Murree region of Pakistan on insulin secretion from INS-1 cells. Phytother Res 18(1):1-7

Ivanov I, Petkova N, Tumbarski J, Dincheva I, Badjakov I, Denev P, Pavlov A (2018) GC-MS characterization of $n$-hexane soluble fraction from dandeIion (Taraxacum officinale Weber ex F.H.Wigg.) aerial parts and its antioxidant and antimicrobial properties. Z Naturforsch C J Biosci. 73(1-2):41-47.

Jedrejek D, Kontek B, Lis B, Stochmal A, Olas B (2017) Evaluation of antioxidant activity of phenolic fractions from the leaves and petals of dandelion in human plasma treated with $\mathrm{H}_{2} \mathrm{O}_{2}$ and $\mathrm{H}_{2} \mathrm{O}_{2} / \mathrm{Fe}$. Chem Biol Interact 262:29-37

Jedrejek D, Lis B, Rolnik A, Stochmal A, Olas B (2019) Comparative phytochemical, cytotoxicity, antioxidant and haemostatic studies of Taraxacum officinale root preparations. Food Chem Toxicol 126:233-247

Karakus A, Deger Y, Yildirim S (2017) Protective effect of Silybum marianum and Taraxacum officinale extracts against oxidative kidney injuries induced by carbon tetrachloride in rats. Ren Fail 39(1):1-6

Kenny O, Brunton NP, Walsh D, Hewage CM, McLoughlin P, Smyth TJ (2015) Characterisation of antimicrobial extracts from dandelion root (Taraxacum officinale) using LC-SPE-NMR. Phytother Res 29(4):526-532

Kim HM, Lee EH, Shin TY, Lee KN, Lee JS (1998) Taraxacum officinale restores inhibition of nitric oxide production by cadmium in mouse peritoneal macrophages. Immunopharmacol Immunotoxicol 20(2):283-297

Lee BR, Lee JH, An HJ (2012) Effects of Taraxacum officinale on fatigue and immunological parameters in mice. Molecules 17:13253-13265
Liang Y, Duan H, Zhang P, Han H, Gao F, Li Y, Xu Z (2020) Extraction and isolation of the active ingredients of dandelion and its antifungal activity against Candida albicans. Mol Med Rep 21:229-239

Lis B, Jedrejek D, Rywaniak J, Soluch A, Stochmal A, Olas B (2020). Flavonoid preparations from Taraxacum officinale L. fruits-A phytochemical, antioxidant and hemostasis studies. Molecules. 25(5402):1-33.

Martinez M, Poirrier P, Chamy R, Prüfer D, SchulzeGronover C, Jorquera L, Ruiz G (2015) Taraxacum officinale and related species - an ethnopharmacological review and its potential as a commercial medicinal plant. J Ethnopharmacol 169:244-262

Milek M, Marcincáková D, Legáth J (2019) Polyphenols content, antioxidant activity, and cytotoxicity assessment of Taraxacum officinale extracts prepared through the micelle-mediated extraction method. Molecules 24(1025):1-14

Nassan MA, Soliman MM, Ismail SA, El-Shazly S (2018) Effect of Taraxacum officinale extract on PI3K/Akt pathway in DMBA-induced breast cancer in albino rats. Biosci Rep. 38BSR20180334.

Nguyen C, Mehaidli A, Baskaran K, Grewal S, Pupulin A, Ruvinov I, Scaria B, Parashar K, Vegh C, Pandey S (2019) Dandelion root and lemongrass extracts induce apoptosis, enhance chemotherapeutic efficacy, and reduce tumour xenograft growth in vivo in prostate cancer. Evid Based Complement Alternat Med. 2951428.

Ovadje P, Ammar S, Guerrero JA, Arnason JT, Pandey S (2016) Dandelion root extract affects colorectal cancer proliferation and survival through the activation of multiple death signalling pathways. Oncotarget 7(45):73080-73100

Ovadje P, Chatterjee S, Griffin C, Tran C, Hamm C, Pandey S (2011) Selective induction of apoptosis through activation of caspase-8 in human leukemia cells (Jurkat) by dandelion root extract. J Ethnopharmacol 133(1):86-91

Ovadje P, Chochkeh M, Akbari-Asl P, Hamm C, Pandey S (2012) Selective induction of apoptosis and autophagy through treatment with dandelion root extract in human pancreatic cancer cells. Pancreas 41(7):1039-1047

Park CM, Cho CW, Song YS (2014) TOP 1 and 2, polysaccharides from Taraxacum officinale, inhibit NFkB-mediated inflammation and accelerate Nrf2-induced antioxidative potential through the modulation of PI3K-Akt signaling pathway in RAW 264.7 cells. Food Chem Toxicol. 66:56-64.

Park CM, Park JY, Noh KH, Shin JH, Song YS (2011). Taraxacum officinale Weber extracts inhibit LPS-induced oxidative stress and nitric oxide production via the NF-KB modulation in RAW 264.7 cells. J Ethnopharmacol. 133(2):834-842.

Park CM, Youn HJ, Chang HK, Song YS (2010) TOP1 and 2, polysaccharides from Taraxacum officinale, attenuate $\mathrm{CCl}_{4}$-induced hepatic damage through the modulation of NF-kB and its regulatory mediators. Food Chem Toxicol 48(5):1255-1261

Qian L, Zhou Y, Teng Z, Du CL, Tian C (2014) Preparation and antibacterial activity of oligosaccharides derived from dandelion. Int J Biol Macromol 64:392-394

Rasool S, Sharma B (2014) Taraxacum officinale: a high value less known medicinal plant. Ann Plant Sci 3(12):908-915

Râcz-Kotilla E, Râcz G, Solomon A (1974) The action of Taraxacum officinale extracts on the body weight and diuresis of laboratory animals. Planta Med 26(7):212-217

Rehman S, ljaz B, Fatima N, Muhammad SA, Riazuddin S (2016) Therapeutic potential of Taraxacum officinale against HCV NS5B polymerase: In-vitro and In silico study. Biomed Pharmacother 83:881-891

Sang R, Yu Y, Ge B, Xu L, Wang Z, Zhang X (2019) Taraxasterol from Taraxacum prevents concanavalin A-induced acute hepatic injury in mice via modulating TLRs/NF-KB and Bax/BC1-2 signalling pathways. Artif Cells Nanomed Biotechnol 47(1):3929-3937

Saratale RG, Benelli G, Kumar G, Kim DS, Saratale GD (2018) Bio-fabrication of silver nanoparticles using the leaf extract of an ancient herbal medicine, dandelion (Taraxacum officinale), evaluation of their antioxidant, anticancer potential, and antimicrobial activity against phytopathogens. Environ Sci Pollut Res Int 25(11):10392-10406

Sigstedt SC, Hooten CJ, Callewaert MC, Jenkins AR, Romero AE, Pullin MJ, Kornienko A, Lowrey TK, Van Slambrouck S, Steelant WFA (2008) Evaluation of aqueous extracts of Taraxacum officinale on growth and invasion of breast and prostate cancer cells. Int J Oncol 32:1085-1090 
Singh A, Malhotra S, Subban R (2008) Dandelion (Taraxacum officinale) hepatoprotective herb with therapeutic potential. Pharmacogn Rev 2(3):163-167

Stewart-Wade SM, Neumann S, Collins LL, Boland GJ. The biology of Canadian weeds. 117. Taraxacum officinale G. H. Weber ex Wiggers. Can J Plant Sci. 2002;82(4):825-853.

Tan X, Sun Z, Chen S, Chen S, Huang Z, Zhou C, Zou C, Liu Q, Ye H, Lin H, Ye C, Wang A (2017) Effects of dietary dandelion extracts on growth performance, body composition, plasma biochemical parameters, immune responses and disease resistance of juvenile golden pompano Trachinotus ovatus. Fish Shellfish Immunol 66:198-206

Wang HB (2014) Cellulase-assisted extraction and antibacterial activity of polysaccharides from the dandelion Taraxacum officinale. Carbohydr Polym 103:140-142

Wang Q, Bie YL, Wang D, Fan WT (2017) Effects of dandelion polysaccharide on IL-6/STAT3 signaling pathway in ulcerative colitis rats. Zhongguo Ying Yong Sheng Li Xue Za Zhi 33(5):422-425
Wang S, Wang Y, Liu X, Guan L, Yu L, Zhang X (2016) Anti-inflammatory and anti-arthritic effects of taraxasterol on adjuvant-induced arthritis in rats. J Ethnopharmacol 187:42-48

Yang Y, Ying G, Wu S, Wu F, Chen Z (2020) In vitro inhibition effects of hepatitis $B$ virus by dandelion and taraxasterol. Infect Agents Cancer 15(44):1-10

You Y, Yoo S, Yoon HG, Park J, Lee YH, Kim S, Oh KT, Lee J, Cho HY, Jun W (2010) In vitro and in vivo hepatoprotective effects of the aqueous extract from Taraxacum officinale (dandelion) root against alcohol-induced oxidative stress. Food Chem Toxicol 48:1632-1637

Zhang J, Kang MJ, Kim MJ, Kim ME, Song JH, Lee YM, Kim JI (2008) Pancreatic lipase inhibitory activity of Taraxacum officinale in vitro and in vivo. Nutr Res Pract 2(4):200-203

\section{Publisher's Note}

Springer Nature remains neutral with regard to jurisdictional claims in published maps and institutional affiliations.

\section{Submit your manuscript to a SpringerOpen ${ }^{\circ}$ journal and benefit from:}

- Convenient online submission

- Rigorous peer review

- Open access: articles freely available online

- High visibility within the field

- Retaining the copyright to your article

Submit your next manuscript at $\boldsymbol{\nabla}$ springeropen.com 